\title{
CHILD DEVELOPMENT: COMPARISON BETWEEN CHILDREN WHO ATTEND OR DO NOT ATTEND PUBLIC DAYCARE CENTRES
}

\author{
Lívia Lúcio de Mattos Amaro', Sávia Alves Pinto', Rosane Luzia de Souza Morais ${ }^{1}$, \\ Jacqueline Alves Tolentino ${ }^{1}$, Larissa Rosa Felício ${ }^{1}$, Ana Cristina Resende Camargos ${ }^{1}$, \\ Fernanda Oliveira Ferreira ${ }^{2}$, Camila Avelar Gonçalves ${ }^{1}$
}

\begin{abstract}
Objective: To avaluate and compare the development of children attending public nursery school from their peers who remain only in the home environment. Methods: We performed an observational, cross-sectional study with 167 children aged between 11 and 57 months from Alto Vale do Jequitinhonha, Minas Gerais, Brazil. The subjects were divided into two groups (nursery and hom areas:e), homogeneous in age, gender, socioeconomic status, and maternal education. The development areas: personal-social, language, and fine and gross motor were evaluated through the Denver II test and the quality of environment of the five public nursery school ' through the Infant/Toddler Environment Rating Scale-Revised Edition (ITERS-R). We used the chi-square statistical test for comparison between groups. Results: There were no significant statistical differences between groups for the overall test result for Denver II, nor for the different areas of the test. The environments presented daycare quality between 'inadequate' and 'minimal'. Thus, there was no difference between attending a low quality daycare or just staying in the home for child development. Conclusion: No difference was observed when comparing the development areas: personal-social, language, and gross and fine motor of child who attend public nursery school and their peers who remained only in the home environment. The daycare environments analysed showed quality considered 'inadequate', which may have influenced the results as the literature has pointed out the need for a quality childcare environment to positively influence child development.
\end{abstract}

DOI: http://dx.doi.org/10.7322/jhgd.103002

Key words: child development, child daycare centres, environmental quality, childcare.

\section{INTRODUCTION}

Child development is a process that consists of continuities and changes in interdependent areas: sensory-motor, cognitive and psychosocial, which are likely to be influenced by biological, genetic and environmental factors ${ }^{1}$. The physical, social, economic, and emotional environments can positively or negatively affect development and promote long-term effects on the brain's function, for example, in achieving academic success and reaching full capacity in adult life ${ }^{2}$.

Home environment organization, parental expectations and practices, experience with various materials, daily stimulation, and the degree of maternal education can influence child development ${ }^{3}$.

Beyond the home, the academic environment has stood out in child development ${ }^{4,5}$. In Brazil, with urbanization, economic growth, social struggles, and the changing role of women in society, children are attending nurseries earlier, where they spend 4 to
12 hours per day ${ }^{5,6}$. The National Plan for Education ${ }^{7}$ determined that by $2011,50 \%$ of children up to three years and $80 \%$ between four and five years old would be enrolled in early childhood institutions, although only the second goal was reached ${ }^{8}$.

National policies encourage the inclusion of these children aiming not only to care for them during the working hours of their mothers, but also the promotion of benefits to child development. According to the United Nations Children's Fund (UNICEF), early child education in nursery school and preschools is fundamental to guarantee the full development of children 7,9 , as well as being an essential right.

Studies claim that although the effects of the day-care environment under different aspects of child development are still quite controver-sial ${ }^{10}$, there is evidence of the benefits of this environment for the development of children in economically disadvantaged situations $\mathbf{s}^{10-12}$.

\footnotetext{
1 Departamento de Fisioterapia da Universidade Federal dos Vales do Jequitinhonha e Mucuri (UFVJM) - Diamantina (MG), Brasil

2 Departamento de Ciências Básicas, Universidade Federal de Juiz de Fora (UFJF) - Campus Governador Valadares - Centro Governador Valadares (MG), Brasil

Corresponding author: Rosane Luzia de Souza Morais. E-mail: rosanesmorais@gmail.com
}

Suggested citation: Amaro LLM, Pinto SA, Morais RLS, Tolentino JÁ, Felício LR, Camargos ACR, et al. Child development: comparison between children who attend or do not attend public daycare centres. Journal of Human Growth and Development. 25(2): 170-176. DOI: http://dx.doi.org/10.7322/jhgd.103002

Manuscript submitted: feb 12 2015. Accepted for publication jun 192014. 
There are some studies in the national literature seeking to verify the influence of daycare centres, among other factors, on different aspects of child development ${ }^{5,12-15}$. However, there is no consensus regarding the influence of this environment on child development and its different domains. Moreover, few studies ${ }^{5,15}$ systematically evaluated the quality of the educational environment, before checking the influence of the environment on child development.

Thus, considering that currently nurseries aim in addition to care, to promote infant development ${ }^{9}$, this study aims to evaluate and compare the childhood development of children attending public nursery school and their peers who only remain in the home environment. Therefore, the quality of the nursery environment was evaluated in a systematic way.

\section{METHODS}

\section{Type of Study and Participants}

This is a cross-sectional study approved by the Ethics Committee (UFVJM 061/10). The study included 167 children aged 11 to 57 months living in the headquarters of a municipality in the Alto Vale do Jequitinhonha, Minas Gerais, Brazil. The children were divided into two groups: the first group, called the NURSERY GROUP, was composed of 83 children enrolled in five public daycare centres in the city. They included all those who returned with the free and informed consent (IC) form signed by a responsible adult and that met the inclusion criteria: minimum frequency of six months of daycare and attending full time.

The other group, called the HOUSE GROUP, was composed of 84 children who did not attend nursery school, whose parents also signed the consent form. To be a part of this group the children should never have attended an educational institution and should be registered in a Family Health Strategy (FHS) in the city. Initially, a survey was conducted of registered children to obtain their home addresses in the FHS of the five neighbourhoods where the children of the NURSERY GROUP lived. From this survey, the first 84 children were evaluated for the HOUSE GROUP, within the age range of 11 to 57 months, whose parents agreed to receive the researchers at home.

The two groups were formed by children from the same neighbourhoods in order to maintain similar sociodemographic conditions. The exclusion criteria of the study were children who presented a congenital disorder or acquired a disease that might interfere with child development.

\section{Instruments}

To evaluate child development it was used the Denver II. It is a well known standardized instrument used in many countries, including Brazil ${ }^{13}$, for screening of children with a risk for developmental delay. The test is divided into four areas: personalsocial, fine motor, language, and gross motor. Items are applied according to the age of each child and are classified as pass, caution or delay. The overall test result is interpreted as normal (no delay/ just a caution), suspect (a delay and/or two or more warrants) or abnormal (two or more delays) ${ }^{16}$.

The Infant/Toddler Environment Rating Scale-Revised (ITERS-R) ${ }^{17}$ was used for qualitative assessment of the kindergartens. It is scale indicated for assessing collective educational environments and is composed of seven subscales: space and furniture, routine and childcare, talk and comprehension, activities, interaction, program structure, parents, and staff. Each item is assigned a score on a scale of 1 to 7 , indicating the quality of service offered: 1 to 2.99 - inadequate; 3 to 4.99 - minimum; 5 to 6.99 - good; and 7 excellent ${ }^{17}$. This scale has shown suitability for use in Brazilian nurseries, pointing to satisfactory levels of reliability between examiners and different quality levels of discrimination capacity ${ }^{18}$. Although originally the ITERS-R was used for evaluating daycare environments for children 0-30 months in this study, the scale was used to evaluate nurseries with older children as well in Lima and Bhering ${ }^{19}$, due to the fact that in most nurseries children with age differences stayed together in the same room.

For the classification of economic status of the families of the children we used the Criteria of Economic Classification Brazil (CECB) of the Brazilian Association Research Companies ${ }^{20}$. It is a classification system according to the belongings and the education level of the householder. The family's economic status is classified into a growing ordinal scale ranging from $E$ to $A_{1}{ }^{20}$.

In addition, the child's responsible answered a questionnaire developed by the researchers to characterize the participants regarding the identification data, such as age, gender, and the level of maternal education.

\section{Procedures}

Initially permits were obtained from the education department and municipal health department. Next, the researchers made contact with the nursey schools teachers and the selection of children registered in the FHS was made. The IC form was given to parents at the time they came to drop off their children at the daycare centres for the NURSERY GROUP and while visiting their homes for the HOUSE GROUP. Similarly, the CECB was answered by the parents through interviews after leaving their children in daycare for the NURSERY GROUP, and at home for the HOUSE GROUP.

Assessments of the NURSERY GROUP were with the nursery school teachers in a reserved space, and the children of the HOUSE GROUP were assessed in their own residence. Before the study, the examiners performed collection, training and calibration to administer the Denver II test and obtained Kappa values ranging between 0.76 and 0.87 . Alongside the application of the Denver II, daycare centres were evaluated using the ITERS-R by a single examiner that was previously trained and blinded to the results of the child development screening test. Each nursery environment was 
visited for a full eight hours, that is the examiner arrived at the site before the children and remained until they were all gone.

\section{Data Analysis}

Data were analysed using the software Statistical Package for the Social Sciences SPSS (version 17.0). To characterize the sample descriptive statistics were used. The Kolmogorov-Smirnov test revealed that the data did not present normal distribution; therefore, nonparametric tests were used. For quantitative data, the Mann-Whitney test was used to compare the results among children of the NURSERY and HOUSE groups. To compare groups of categorical variables, we used the chi-square test. This study adopted the significance level of $p<0.05$.

\section{RESULTS}

\section{Sample Characterization}

Tables 1 and 2 present results of the sample according to age in months, gender, economic status, and maternal education. The HOUSE GROUP and NURSERY GROUP showed no statistically significant differences in these variables. Most children belong to economically disadvantaged families (C2, D, and E): $80.6 \%$ in the NURSERY group and $76.2 \%$ in the HOUSE GROUP. As for maternal education, it was observed that most of the mothers did not complete high school: $73.5 \%$ of the mothers in the NURSERY GROUP and $69.0 \%$ in the HOUSE GROUP (Tables 1 and 2).

Table 1: Sample characteristics and comparisons between the groups regarding age in months

\begin{tabular}{lccccc} 
& \multicolumn{2}{c}{$\begin{array}{c}\text { Number of } \\
\text { participants }\end{array}$} & \multicolumn{2}{c}{ Age (months) } & \\
& & Minimum-Maximum & x (SD) & Mann-Whitney & P \\
NURSERY GROUP & 83 & $11-57$ & $33.90( \pm 11.41)$ & & \\
HOME GROUP & 84 & $11-56$ & $31.65( \pm 11.24)$ & 3103.000 & 0.220 \\
-TOTAL & 167 & $11-57$ & $32.78( \pm 11.35)$ & &
\end{tabular}

$\mathrm{x}=$ Mean; SD = Standard Deviation; $\mathrm{p}=$ significance of the statistical test.

Table 2: Characterization of the participants and comparison of the groups regarding gender, economic, and maternal education levels.

\begin{tabular}{|c|c|c|c|c|c|}
\hline & NURSERY GROUP n (\%) & HOME GROUP n (\%) & $\mathbf{X}^{2}$ & $\mathbf{p}$ & TOTAL \\
\hline Genre & & & 0.006 & 0.936 & \\
\hline Female & $43(51.81 \%)$ & $43(51.19 \%)$ & & & $86(51.50 \%)$ \\
\hline Male & $40(48.19 \%)$ & $41(48.81 \%)$ & & & $81(48.50 \%)$ \\
\hline Economic Level & & & 3,638 & 0.457 & \\
\hline$B^{2}$ & $2(2.41 \%)$ & $5(5.95 \%)$ & & & $7(4.19 \%)$ \\
\hline $\mathrm{C}_{1}$ & $14(16.87 \%)$ & $15(17.86 \%)$ & & & $29(17.37 \%)$ \\
\hline$C^{2}$ & $31(37.35 \%)$ & $38(45.24 \%)$ & & & $69(41.32 \%)$ \\
\hline D & $29(34.94 \%)$ & $21(25.00 \%)$ & & & $50(29.94 \%)$ \\
\hline E & $7(8.43 \%)$ & $5(5.95 \%)$ & & & $12(7.19 \%)$ \\
\hline Maternal Education & & & 4,602 & 0.708 & \\
\hline $\mathrm{CHE}$ & $3(3.61 \%)$ & $2(2.38 \%)$ & & & $5(2.99 \%)$ \\
\hline IHE & $0(0.00 \%)$ & $1(1.19 \%)$ & & & $1(0.60 \%)$ \\
\hline $\mathrm{CHS}$ & $19(22.89 \%)$ & $23(27.38 \%)$ & & & $42(25.15 \%)$ \\
\hline ISE & $16(19.28 \%)$ & $16(19.04 \%)$ & & & $32(19.16 \%)$ \\
\hline CPE & $8(9.64 \%)$ & $8(9.52 \%)$ & & & $16(9.58 \%)$ \\
\hline IEE & $21(25.30 \%)$ & $16(19.05 \%)$ & & & $37(22.16 \%)$ \\
\hline CPE & $4(4.82 \%)$ & $9(10.71 \%)$ & & & $13(7.78 \%)$ \\
\hline IPE & $12(14.46 \%)$ & $9(10.71 \%)$ & & & $21(12.57 \%)$ \\
\hline
\end{tabular}

$\mathrm{n}=$ total number of participants; $\%=$ percentage; $\mathrm{CHE}=$ Completed higher education; IHE = Incomplete higher education; CHS = Completed high school; ISE = Incomplete secondary education; CPE = Completed primary education; $\mathrm{IEE}=$ Incomplete elementary education; CPE = Completed primary education; and $\mathrm{IPE}=$ Incomplete primary education; $\mathrm{p}=$ significance of the statistical test.

\section{Denver II Test Results}

Table 3 shows the results of the general development and personal-social, fine motor, gross motor, and language assessments. It is observed that for general results there was a big percentage on suspect tests added to the abnormal tests, but with higher values for the 
HOUSE GROUP $(40,47 \%)$ in relation to the NURSERY GROUP $(37,35 \%)$.

However, when the HOUSE GROUP and NURSERY GROUP were compared using statistical tests, there were no significant differences between them for the global Denver II test or for different test domains (Table 3).

Table 3: General Denver II test results according to each domain

\begin{tabular}{|c|c|c|c|c|c|}
\hline & NURSERY n (\%) & HOME n (\%) & $\mathbf{X}^{2}$ & $\mathbf{p}$ & TOTAL \\
\hline DENVER II & & & 0.888 & 0.642 & \\
\hline Normal & $52(62.65 \%)$ & $50(59.52 \%)$ & & & $102(61.68 \%)$ \\
\hline Suspect & $25(30.12 \%)$ & $30(35.71 \%)$ & & & $55(32.93 \%)$ \\
\hline Abnormal & $6(7.23 \%)$ & $4(4.76 \%)$ & & & $10(5.99 \%)$ \\
\hline Personal Social & & & 3.030 & 0.082 & \\
\hline Without caution or delay & $66(79.52 \%)$ & $75(89.29 \%)$ & & & $141(84.43 \%)$ \\
\hline Caution or delay & $17(20.49 \%)$ & $9(10.71 \%)$ & & & $26(15.57 \%)$ \\
\hline Fine motor & & & 0.002 & 0.965 & \\
\hline no caution or delay & $63(75.90 \%)$ & $64(76.19 \%)$ & & & $127(76.05 \%)$ \\
\hline Caution or delay & $20(24.10 \%)$ & $20(23.81 \%)$ & & & $40(23.95 \%)$ \\
\hline Language & & & 0.050 & 0.823 & \\
\hline no caution or delay & $47(56.63 \%)$ & $49(58.33 \%)$ & & & $96(57.49 \%)$ \\
\hline Caution or delay & $36(43.37 \%)$ & $35(41.67 \%)$ & & & $71(42.51 \%)$ \\
\hline Gross Motor & & & 0.183 & 0.669 & \\
\hline S / caution or delay & $73(87.95 \%)$ & $72(85.71 \%)$ & & & $145(86.83 \%)$ \\
\hline Caution or delay & $10(12.05 \%)$ & $12(14.29 \%)$ & & & $22(13.17 \%)$ \\
\hline
\end{tabular}

$\mathrm{n}=$ absolute number of children; $\mathrm{p}=$ significance of the statistical test.

The statistical power for each of the developmental domains analysed ${ }^{21}$ was calculated by comparing the results of children who attended daycare or not from the magnitude of the effect obtained in the chi-square test. For the personalsocial domain a statistical power of $81 \%$ was obtained; fine motor was $75 \%$, language was $85 \%$, and gross motor was $60 \%$.

\section{Quality of the Environment of Nursey School}

The results showed that the quality of five nurseries was considered 'poor' with scores of at least 1.91 and at most 2.92. Figure 1 shows the average of the five kindergartens for each subscale and total result of daycare quality. In this case, the subscale or ITERS-R total reached the required minimum score (3.0) to be considered minimally adequate.

Figure 1: Mean quality of childcare considering the subscales and the total ITERS-R - Diamantina, Minas Gerais, Brazil - 2010



\section{DISCUSSION}

According to the National Law of Education Bases and Guidelines, early childhood education is a stage of basic education that aims to serve children from zero to six years to promote physical, psychological, social, and intellectual development. Thus, the present study examined whether children enrolled in public daycare centres benefit from attending a child development environment in comparison to their peers who remain only in the home environment.

When considering the home environment factors, the literature has extensively documented the socio-economic level and degree of maternal education are factors that can influence infant development $2,3,5,10,11,22$. Therefore, we tried to ensure that initially the HOUSE GROUP and NURSERY GROUP were homogeneous regarding these variables, as well as age and gender ${ }^{23}$, so that these factors did not interfere with the investigation: how often a child attends daycare and the effect in child development.

It was found that most children from both the HOUSE GROUP and NURSERY GROUP belonged to low-income families and their mothers had not completed high school, which shows the presence of risk factors for development in both groups. The literature has shown that children growing up in unfavourable socio-economic conditions become more vulnerable to late development ${ }^{2,3,5,10,11,22}$.

The results obtained using the Denver II test showed that $30.12 \%$ of the NURSERY GROUP and $35.71 \%$ of the HOUSE GROUP presented results considered 'suspicious'. Although the NURSERY GROUP presented a lower percentage, there was no statistically significant difference between them. However, this finding draws attention to the high prevalence of test 'suspects' in this study. This result was also found by other $b^{\prime}$ razilian researchers ${ }^{24-26}$ who applied a screening test on children from public and philanthropic daycare centres, with similar or close to the ages 
of the children in the present study. Biscegli et al. ${ }^{24}$, Souza et al. ${ }^{25}$ and Brito et al. ${ }^{26}$ found a prevalence of suspected delays in global development, $37 \%, 30.2 \%$, and $46.7 \%$ respectively when using the Denver II.

In this study, when considering the total sample, language and gross motor domain were those with respectively the highest and lowest number of 'cautions' and 'delays'. Similar results were found in other Brazilian studies ${ }^{13,24,26}$.

The child development comparison analysis showed no significant difference between the HOUSE GROUP and the NURSERY GROUP; therefore, attending daycare did not provide better outcomes for child development of these children in any of the analysed domains. Lordelo et al. ${ }^{14}$ also found similar results when assessing the cognitive development of 18 children who attended daycare compared with 19 children who remained at home, all with unfavourable socioeconomic conditions. No significant difference was observed between the groups; however, the authors point out as study limitations the small sample size and the focus only on the field of cognition. Moreover, the quality of the educational environment was not assessed.

Studies have demonstrated the importance of the quality of educational environments for infant development $\mathrm{t}^{5,10,11,15}$. Barros et al. ${ }^{15}$, using a random sample of 500 children from 100 daycare centers in the city of Rio de Janeiro, Brazil, noted the impact of the quality of daycare on child development controlling for the influences of the child's family and personal characteristics. The authors found moderate impact of daycare quality on global, social, and mental development of children and no impact on physical development.

In another study on the impact of the quality of early childhood education in school performance, Campos et al. ${ }^{5}$ found that attending kindergarten, particularly those of better quality, made a difference in the performance of 762 children on the Provinha Brazil exam, a diagnostic assessment of the level of literacy of Brazilian public schools. Factors related to family environment, such as family income and maternal education, also had an impact on the results. However, even controlling for family factors, children who go to good quality preschools compared with those who did not attend preschool obtained a $12 \%$ increase in the scale of notes on the Provinha Brazil exam.

\section{REFERENCES}

1. Bronferbrenner U. Bioecologia do desenvolvimento humano: tornando os seres humanos mais humanos. Porto Alegre: Artmed; 2011.

2. Grantham-Mcgregor S, Cheung YB, Cueto S, Glewwe P, Richter L, Strupp B et al. Developmental potential in the first 5 years for children in developing countries. Lancet. 2007; 369 (9555): 60-70. DOI: http://dx.doi.org/ 10.1016/S0140-6736(07)60032-4
Authors ${ }^{10,11}$ such as Engle et al. ${ }^{10}$ state that nurseries play an important role in promoting the development of economically disadvantaged children and can bring significant benefits; however, it is necessary that the environments are of good quality. In this study, on average the quality of daycare centers was 'inadequate', both for the overall result and for each subscale, which may have influenced the results in which the NURSERY GROUP did not perform better in comparison to the HOUSE GROUP's performance in the various areas of child development.

The quality of the environment found in this study is in agreement with public daycare centres studied by other Brazilian authors 5,6,19,27. In general, the public daycare centres in Brazil function poorly, with limited resources, lack of infrastructure, and a lack of preparation of its employees and adoption of routines with a predominance of actions for feeding and sanitizing, among others ${ }^{6,27}$. Therefore, in addition to government incentives for insertion of a greater number of children in Nursey school, it is necessary to invest in quality childcare ${ }^{7}$ for these educational environments to comply with the goal of bringing developmental benefits to infants ${ }^{9}$.

In relation to this study it is important to note that a developmental screening test was used. Screening tests do not have a diagnostic function, but indicate the need for more detailed research ${ }^{28}$. Another aspect to consider is that the study showed a statistical power of less magnitude ${ }^{21}$ for the gross motor domain, which implies greater caution in interpreting the findings for this domain. In addition, it is recommended that in future studies the quality of the home environment and socio-economic indicators such as maternal education and economic level used in this study are also examined.

\section{CONCLUSION}

This study found no significant difference when comparing the areas of personal-social, language, gross motor, and fine motor development in children attending public nursery school and their peers who remained only in the home environment.

The quality of the daycare environments analysed were shown to be 'inadequate', which may have influenced the results because the literature has pointed out the need for quality childcare environments to positively influence child development.

3. Bradley RH, Corwyn RF. Socioeconomic status and child development. Annu Rev Psychol. 2002; 53: 371-99. DOI: http://dx.doi.org/ 10.1146/annurev.psych.53.100901.135233

4. Fundo das Nações Unidas para a Infância (UNICEF). Situação mundial da infância 2008: sobrevivência infantil. [cited 2010 Sep 08] Available from: http://www.unicef.org/brazil/ pt/cadernobrasil2008.pdf.

5. Lordelo ER, Chalhub AA, Guirra RC, Carvalho CS. Contexto e desenvolvimento cognitivo: freqüência à creche e evolução do desenvol- 
vimento mental. Psicol Reflex Crít. 2007; 20 (2): 324-334. DOI: http://dx.doi.org/10.1590/ S0102-79722007000200019

6. Pacheco ALPB, Dupret L. Creche: desenvolvimento ou sobrevivência? Psicol USP. 2004; 15(3): 103-116. DOI: http://dx.doi.org/ 10.1590/S0103-65642004000200006

7. Brasil. Presidência da República. Lei no 10.172, de 09 de janeiro de 2001. Aprova o Plano Nacional de Educação e dá outras providências. [cited 2015 Jun 18] Available from: http://www.planalto.gov.br/ccivil_03/leis/ leis_2001/l10172.htm

8. Programa das Nações Unidas para o Desenvolvimento (PNDU). Os objetivos de desenvolvimento do milênio. [cited 2014 Oct. 20] Available from: http://www.pnud.org.br/ ODM.aspx.

9. Vieira LMF. A educação infantil e o plano nacional de educação: as propostas da CONAE 2010. Educ Soc Campinas: 2010; 31(112): 809-831. DOI: http://dx.doi.org/10.1590/ S0101-73302010000300009

10. Bradley $\mathrm{RH}$, Vandell DL. Child care and the well-being of children. Arch Pediatr Adolesc Med. 2007; 161(7):669-76. DOI: http:// dx.doi.org/10.1001/archpedi.161.7.669

11. Engle PL, Black MM. The effect of poverty on child development and educational outcomes. Ann N Y Acad Sci 2008; 1136(1): 243-56. DOI: http://dx.doi.org/10.1196/annals.1425.023

12. Reynolds AJ, Temple JA, Ou SR, Robertson DL, Mersky JP, Topitzes JW, et al. Effects of a school-based, early childhood intervention on adult health and well-being: a 19-year followup of low-income families. Arch Pediatr Adolesc Med. 2007; 161(8): 730-9. DOI: http:// dx.doi.org/10.1001/archpedi.161.8.730

13. Rezende MA, Beteli VC, Santos JLF. Avaliação de habilidades de linguagem e pessoal-sociais pelo Teste de Denver II em instituições de educação infantil. Acta Paul Enferm. 2005; (1): 56-63. DOI: http://dx.doi.org/10.1590/ S0103-21002005000100008

14. Santos DCC, Tolocka RE, Carvalho J, Heringer LRC, Almeida CM, Miquelote AF. Desempenho motor grosso e sua associação com fatores neonatais, familiares e de exposição à creche em crianças até três anos de idade. Rev Bras Fisioter. 2009; 13(2): 173-179. DOI: http://dx.doi.org/10.1590/S141335552009005000025

15. Barros RP, Carvalho M, Franco S, Mendonça RSP, Rosalém A. Uma avaliação do impacto da qualidade da creche no desenvolvimento infantil. Pesq Planej Econômico. 2011; 41(2):213-232.

16. Frankenburg WK, Dodds J, Archer P, Shapiro $\mathrm{H}$, Bresnick B. The Denver II: a major revision and restandardization of the Denver Develo- pmental Screening Test. Pediatrics. 1992; 89(1): 91-7.

17. Harms T, Cryer D, Clifford R. Infant/toddler environment rating Scale, revised edition (ITERSR). Frank Porter Graham Child Development Center, University of North Carolina at Chapel Hill. Chapel Hill: Teachers College Press; 2006.

18. Souza TN, Campos-de-Carvalho M. Qualidade de ambientes de creches: uma escala de avaliação. Psicol Estudo. Maringá: 2005; 10(1): 87-96.

19. Lima ABR, Bhering E. Um estudo sobre creches como ambiente de desenvolvimento. Cad Pesq. 2006; 36 (129): 573-596.

20. Associação Brasileira de Empresas de Pesquisa (ABEP). Critério de classificação econômica Brasil. [Cited 2011 Oct 20]. Available from: http://www.abep.org/novo/ Content.aspx?ContentID $=301$.

21. JekeL JF, Katz DL, Elmore JG. Epidemiology, biostatistics, and preventive medicine. 2.ed. Atlanta: Elsevier; 2001.

22. Biscegli TS, Polis LB, Santos LM, Vicentin M. Avaliação do estado nutricional e do desenvolvimento neuropsicomotor em crianças frequentadoras de creche. Rev Paul Pediatr. 2007; 25(4): 337-42. DOI: http://dx.doi.org/ $10.1590 /$ S0103-05822007000400007

23. Souza SC, Leone C, Takano OA, Moratelli HB. Desenvolvimento de pré-escolares na educação infantil em Cuiabá, Mato Grosso, Brasil. Cad Saúde Pública 2008; 24(8):1917-26. DOI: http://dx.doi.org/10.1590/S0102$311 \times 2008000800020$

24. Petterson SM, Albers AB. Effects of poverty and maternal depression on early child development. Child Dev. 2001; 72(6): 17941813. DOI: http://dx.doi.org/10.1111/14678624.00379

25. Carvalho AM, Pereira AS. Qualidade em ambientes de um programa de educação infantil pública. Psicol Teor Pesq. 2008; 24(3): 269277. DOI: http://dx.doi.org/10.1590/ S0102-37722008000300002

26. Howes C. Can the age of entry and the quality of infant child care predict adjustments in kindergartens? Dev Psychol. 1990; 26(2): 252-303. DOI: http://dx.doi.org/0.1037/00121649.26.2.292

27. NICHD Early Child Care Research Network. Child care and family predictors of preschool attachment and stability from infancy. Dev Psychol. 2001; 37(6): 847-862. DOI: http:// dx.doi.org/10.1037/0012-1649.37.6.847

28. Zeppone SC, Volpon LC Del Ciampo LA. Monitoramento do desenvolvimento infantil realizado no Brasil. Rev Paul Pediatr. 2012; 30(4): 594-9. DOI: http://dx.doi.org/10.1590/ S0103-05822012000400019 


\section{RESUMO}

Objetivo: Avaliar e comparar o desenvolvimento infantil de crianças que frequentam creches públicas e seus pares que permanecem apenas em ambiente domiciliar. Método: Foi realizado um estudo observacional, transversal, com 167 crianças entre 11 a 57 meses, dividida em dois grupos (CRECHE e CASA) homogêneos quanto à idade, gênero, nível econômico e escolaridade materna. Os domínios do desenvolvimento pessoal-social, linguagem, motor fino e motor grosso foram avaliados através do teste Denver II e a qualidade do ambiente das cinco creches públicas através da Infant/Toddler Environment Rating Scale-Revised Edition. Foram utilizados os testes estatísticos Mann-Whitney e Qui-quadrado para a comparação entre os dois grupos. Resultados: Não foram encontradas diferenças estatisticamente significativas entre os grupos para o resultado geral do teste Denver II, nem para os diferentes domínios do teste. Os ambientes de creche apresentaram qualidade considerada "inadequada". Conclusão: Não foi observada diferença ao comparar os domínios do desenvolvimento pessoal-social, linguagem, motor grosso e motor fino de crianças que frequentavam creches públicas e seus pares que permaneciam apenas em ambiente domiciliar. Os ambientes de creche analisados apresentaram qualidade considerada "inadequada", o que pode ter influenciado nos resultados, visto que a literatura tem apontado a necessidade de um ambiente de creche de qualidade para que haja influência positiva no desenvolvimento infantil.

Palavras-chave: Desenvolvimento Infantil, creches, qualidade ambiental, cuidado da criança. 